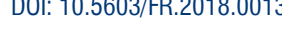

V M

VIA MEDICA

www.fr.viamedica.pl

\title{
Choroba Pageta kości
}

\section{Pagel's diserease of hones}

\section{STRESZCZENIE}

Choroba Pageta kości jest drugą pod względem częstości występowania, po osteoporozie, chorobą metaboliczną kości osób w starszym wieku. Z uwagi na różnorodny obraz kliniczny i bezobjawowy przebieg w początkowym okresie choroby prawidłowe jej zdiagnozowanie może nastręczać trudności. W niniejszej pracy przedstawiono przypadek pacjentki, u której od czasu zauważenia pierwszych objawów w postaci deformacji kości sklepienia czaszki do po- stawienia rozpoznania minęło kilka lat. Tymczasem usytuowanie ogniska choroby w obrębie czaszki to nie tylko problem jej zniekształcenia. Efektem ucisku zmienionej chorobowo kości na nerwy czaszkowe mogą być także poważne powikłania, takie jak pogorszenie wzroku czy głuchota, a szybkie wdrożenie terapii bisfosfonianami u pacjentów z objawami choroby może prowadzić do uzyskania remisji.

Forum Reumatol. 2018, tom 4, nr 4: 238-242

Stowa kluczowe: choroba Pageta; etiopatogeneza; leczenie farmakologiczne

\section{WSTẸP}

Choroba Pageta, opisana po raz pierwszy w 1876 roku, jest przewlekłą chorobą metaboliczną kości polegającą na ogniskowym zaburzeniu fizjologicznej równowagi pomiędzy aktywnością resorpcyjną osteoklastów i aktywnością kościotwórczą osteoblastów, prowadzącą do nieuporządkowanej przebudowy tkanki kostnej objawiającej się zniekształceniem kości [1]. W około $85 \%$ przypadków zmiany są jednoogniskowe i najczęściej dotyczą kości czaszki, miednicy, kręgów, kości udowej i piszczelowej [2]. Choroba występuje u osób w starszym wieku, najwyższa zapadalność notowana jest w ósmej dekadzie życia, częściej u mężczyzn niż kobiet (1,4:1 [1]). Zauważa się geograficzne zróżnicowanie w zapadalności - w Europie najwyższe jest ono w Anglii i Walii, na świecie w Australii i Nowej Zelandii. W Wielkiej Brytanii ogólna zachorowalność $w$ populacji powyżej 55. roku życia szacowana jest na około $3 \%$, w ósmej dekadzie życia wynosi ona $8 \%$ wśród mężczyzn i 5\% wśród kobiet [3]. Obecnie stwierdza się spadek zachorowalno- ści na chorobę Pageta kości, łagodniejszy jej przebieg oraz początek choroby u pacjentów w coraz starszym wieku $[4,5]$. Badania przeprowadzone w ostatnich latach istotnie poszerzyły wiedzę na temat etiopatogenezy choroby Pageta kości. U chorych, zwłaszcza z postacią wieloogniskową, wykazano znacznie podwyższone stężenie ligandu aktywatora receptora jądrowego czynnika $\kappa$ B (RANKL, receptor activator of nuclear factor $\kappa$ B ligand) oraz, w mniejszym stopniu, osteoprotegeryny (OPG, osteoprotegerin) w surowicy krwi i zwiększone stężenie IL-6 [6]. Stwierdzono także, że u chorych na chorobę Pageta komórki zrębu kości wykazują obecność RANKL i stymulują aktywność osteoklastów za pośrednictwem receptora RANK. Osteoklasty wykazują nadmierną reakcje na RANKL oraz aktywny metabolit witaminy D $\left(1,25-(\mathrm{OH})_{2} \mathrm{D}_{3}\right)$. Charakteryzują się ponadto zwiększoną ekspresją podjednostki podstawowego czynnika transkrypcyjnego TFIID będącego składnikiem kompleksu inicjującego transkrypcję z udziałem polimerazy RNAII (TAFII-17, TBP-associated factor II), który pełni funkcję koaktywatora transkrypcji 
mediowanej przez receptor witaminy D [6]. Obecnie coraz więcej wiadomo również na temat znaczenia czynników genetycznych dla rozwoju choroby. Około 40-50\% przypadków rodzinnego występowania wiąże się z mutacją genu SQSTM1 prowadzącą do zaburzeń układu RANK-RANKL-OPG [2], a w konsekwencji do zaburzeń aktywacji i różnicowania prekursorów osteoklastów. Rzadziej występujące mutacje w genach TNFRSF11B kodującym OPG lub TNFRSF11A kodującym RANK wiążą się z występowaniem postaci młodzieńczych, które charakteryzują się szybkim remodelingiem kostnym i już we wczesnym dzieciństwie moga prowadzić do głuchoty, utraty zębów, deformacji i złamań kości, a także, u niektórych pacjentów, do rozwoju w przyszłości osteosarcoma [7]. Prawdopodobnie jednak dopiero nakładanie się predyspozycji genetycznych oraz czynników środowiskowych prowadzi do rozwoju objawów choroby. Jako jeden z czynników etiologicznych choroby rozważa się przewlekłą infekcję wirusową. W 1977 roku Rebel i wsp., a w 1979 roku Basle i wsp. opisali obecność w osteoklastach chorych ciałek wtrętowych przypominających nukleokapsydy paramyksowirusów [8, 9]. Stwierdzono również, że ekspresja białka nukleokapsydowego wirusa odry (MVNP, measles virus nucleocapsid protein) w osteoklastach prowadzi do ich transformacji w komórki przypominające osteoklasty występujące w chorobie Pageta, zwiększenie ich wrażliwości na $1,25-(\mathrm{OH})_{2} \mathrm{D}_{3}$ oraz produkcji IL-6 i TAFII17 [10]. Choć istnieją także badania, które nie potwierdzają związku zaburzeń immunologicznych w przebiegu zakażenia wirusem odry (MV), RSV, nosówki (CDV) a rozwojem choroby Pageta, to jednak u części badanych chorych stwierdzono znacząco podwyższone stężenie przeciwciał przeciwko wirusowi świnki [11].

\section{OPIS PRZYPADKU}

Pacjentka 65-letnia przyjęta do Kliniki Reumatologii i Rehabilitacji w Poznaniu, z podejrzeniem choroby Pageta kości, celem potwierdzenia rozpoznania oraz leczenia. W wywiadzie od około 5 lat guzy kości sklepienia czaszki widoczne oraz wyczuwalne palpacyjnie. W tym czasie kilkukrotne wizyty u lekarzy różnych specjalności, nieskutkujące żadnym postępowaniem diagnostycznym. Ponadto w wywiadzie ovariectomia w 38 roku życia, osteoporoza ze złamaniem kompresyjnym trzonu kręgu L2 i L3 (2009 r.), choroba niedokrwienna serca, zmiany niedokrwienne ośrodkowego układu nerwowego (w CT głowy wykonanym ambulatoryjnie pojedyncze ognisko poudarowe) oraz jaskra. Przy przyjęciu chora nie podawała żadnych dolegliwości. W badaniu przedmiotowym stan ogólny dobry, poza widocznymi i wyczuwalnymi deformacjami w obrębie kości pokrywy czaszki, bez innych odchyleń. W badaniu rentgenowskim opisano równomiernie pogrubiałą strukturę kostną, bez ubytków (ryc. 1), wysunięto podejrzenie choroby Pageta (,„możliwy obraz za ciasnego kapelusza w przebiegu choroby"). Wykonano także badanie scyntygraficzne, uwidaczniając rozlany, zwiększony wychwyt znacznika pośrodkowo, w sklepieniu czaszki. Na podstawie obrazu klinicznego, wyników badań radiologicznych oraz podwyższonej aktywności fosfatazy zasadowej postawiono rozpoznanie choroby Pageta i zastosowano doustny bisfosfonian (Osagrand $150 \mathrm{mg} 1 \times \mathrm{w}$ miesiącu). W kontrolnych badaniach laboratoryjnych, wykonanych po 6 miesiącach leczenia, stwierdzono normalizację wartości fosfatazy zasadowej, prawidłowe stężenie wapnia. W leczeniu utrzymano doustny ibandronian $\mathrm{z}$ dodatkową suplementacją witaminy D.

\section{DYSKUSJA}

Choroba Pageta kości rozwija się fazowo, a objawy kliniczne i radiologiczne zmieniają się w czasie jej trwania. Jak w przypadku przedstawionej powyżej pacjentki, często przebiega bezobjawowo (ok. 70\% [6]), a u części chorych pozostaje nierozpoznana. O chorobie Pageta w diagnostyce różnicowej warto pamiętać nie tylko u pacjentów z deformacjami kostnymi (występują u 12-36\% chorych [12]). Dolegliwości bólowe ze strony kości i stawów to najczęstszy objaw, obecny u 40-45\% pacjentów [12], mogący wynikać z deformacji kości, zmian zwyrodnieniowo-wytwórczych, objawów uciskowych, złamań kości (najczęściej w obrębie trzonów kręgów). Kolejne pod względem częstości występowania to objawy neurologiczne, skutek ucisku nerwów czaszkowych mogący powodować głuchotę, zaburzenia widzenia, bóle głowy oraz zespoły korzeniowe. Rzadziej występują zespoły podkradania tętnicy szyjnej zewnętrznej, wtórna nadczynność przytarczyc, niewydolność serca związana z krążeniem hiperkinetycznym. Opisano także przypadki współwystępowania nowotworów kości, jak osteosarcoma (poniżej 1\% chorych [2]), fibrosarcoma, chondrosarcoma, histiocytoma 

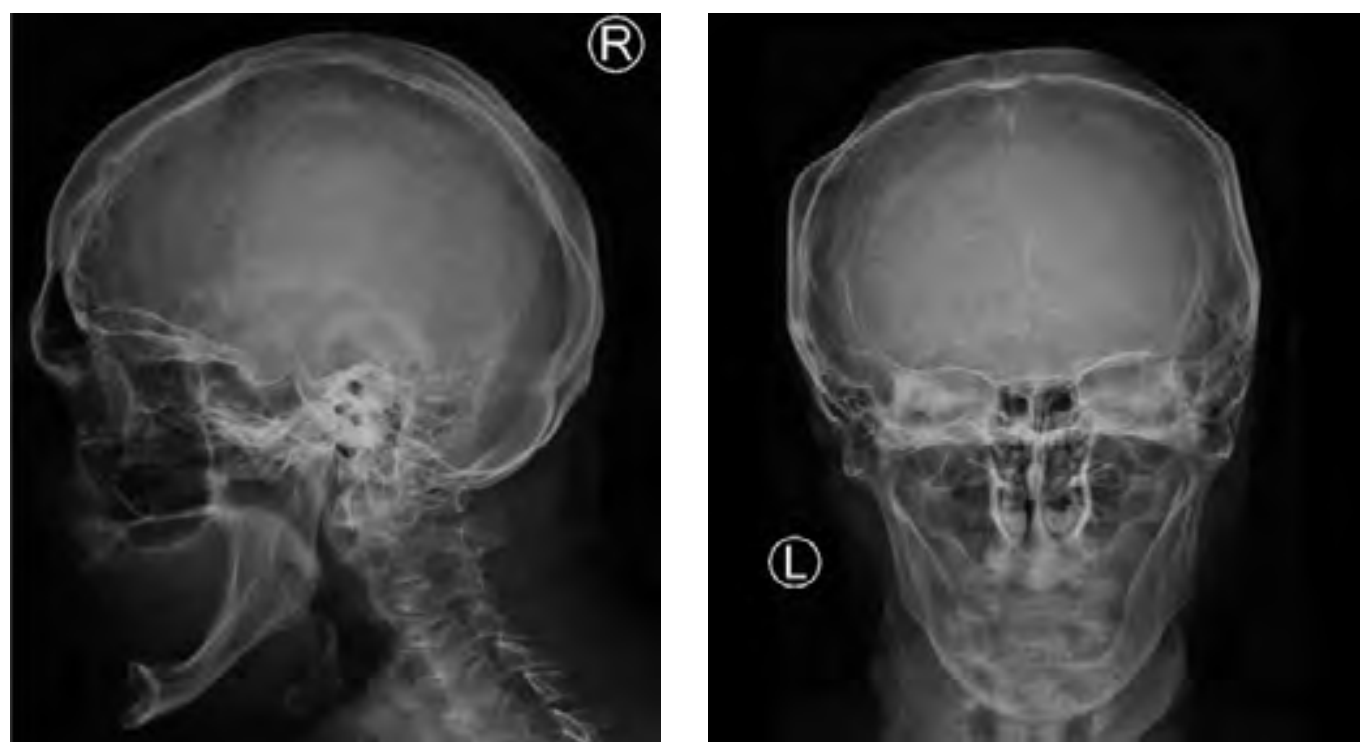

Rycina 1. Hiperostoza kości sklepienia czaszki w przebiegu choroby Pageta

czy guza olbrzymiokomórkowego kości [13]. Wskaźnikami obrotu kostnego pozwalającymi na obiektywną ocenę aktywności choroby Pageta są markery kościotworzenia: fosfataza zasadowa, osteokalcyna (OC), propeptyd prokolagenu typu1 (PINP) oraz resorpcji kostnej: hydroxyprolina, telopeptydy (C-końcowy usieciowany telopeptyd łańcucha alfa-kolagenu typu I, N-końcowy telopeptyd łańcucha alfa kolagenu typu I [NTX, CTX]), pirydolina (PYD) i deoxypirydolina (DPD). U opisanej pacjentki rozpoznanie choroby Pageta kości potwierdzono, uzyskując podwyższoną aktywność fosfatazy zasadowej w surowicy krwi. Z uwagi na łatwą dostępność, niskie koszty oraz dobrą korelację z aktywnością i rozległością procesu chorobowego oznaczenie aktywności fosfatazy zasadowej (ALP) w surowicy krwi jest podstawowym parametrem laboratoryjnym, nie tylko diagnostycznym, ale pozwalającym również monitorować skuteczność leczenia [14]. Należy jednak pamiętać, że aktywność fosfatazy zasadowej jest podwyższona tylko u około $14 \%$ chorych, a prawidłowa aktywność ALP nie wyklucza rozpoznania [12]. Wartość ALP może być także nieproporcjonalnie zawyżona w przypadku zajęcia kości czaszki [14]. W monitorowaniu choroby oraz efektów leczenia znalazły zastosowanie także oznaczenia frakcji kostnej ALP, P1NP oraz NTX [14]. Osteokalcyna, wydzielana przez osteoblasty, wzrasta mniej proporcjonalnie w stosunku do aktywności choroby w porównaniu z pozostałymi markerami kościotworzenia (ALP, P1NP) i wykazuje mniejszy spadek w trakcie leczenia, co częściowo można wytłumaczyć jej krótkim czasem półtrwania spowodowanym szybkim katabolizmem w nerkach oraz działaniem proteaz osoczowych. Także oznaczanie hydroxyproliny, której część nie pochodzi z kości, zaczyna być zastępowane monitorowaniem bardziej swoistych produktów rozpadu kolagenu [14]. Opisana w wyniku badania radiologicznego pacjentki hiperostoza kości sklepienia czaszki, będąca rzadkim objawem, świadczy o długotrwałym procesie chorobowym. Występuje ona, gdy tworzenie kości nie było poprzedzone obecnością zmian resorpcyjnych i charakteryzuje się pogrubieniem oraz sklerotyzacją całej lub części pokrywy czaszki [6]. Choć podstawowym badaniem obrazowym w rozpoznawaniu choroby Pageta kości pozostają nadal zdjęcia rentgenowskie, warto zwrócić uwagę na przydatność badania scyntygraficznego, szczególnie w przypadku wieloogniskowego zajęcia szkieletu. Natomiast tomografia komputerowa i rezonans magnetyczny pozwalają wykryć zmiany we wczesnym okresie oraz powikłania choroby, na przykład stenozę kanału kręgowego czy wtórne nowotwory. W wątpliwych przypadkach wskazana jest biopsja kości. U przedstawionej chorej, po postawieniu rozpoznania, zastosowano praparat bisfosfonianu, gdyż ta grupa leków rekomendowana jest do leczenia pacjentów z objawami choroby. Zaleca się: zolendronian $5 \mathrm{mg}$ i.v. jednorazowo, alendronian $40 \mathrm{mg}$ p.o. $1 \times$ /dobę przez 6 miesięcy, ryzendronian $30 \mathrm{mg}$ p.o. $1 \times$ /dobę przez 2 miesiące, pamidronian $30 \mathrm{mg}$ i.v. przez kolejne $3 \mathrm{dni}$ [12]. Za lek o najwyższej skuteczności uznaje 
się zolendronian. Udowodniono, że jednorazowe dożylne podanie leku u większości pacjentów w starszym wieku zapewnia długotrwałą remisję [15]. W badaniach klinicznych stwierdzono, że $98 \%$ pacjentów leczonych zolendronianem, którzy osiągnęli remisję w postaci normalizacji wartości ALP w surowicy krwi po 6 miesiącach leczenia, utrzymało ją także po 2 latach [16]. Głównym wskazaniem do włączenia leczenia są objawy neurologiczne spowodowane uciskiem zniekształconych kręgów na rdzeń kręgowy oraz nerwy, dolegliwości bólowe, utrata słuchu, niewydolność serca ze zwiększoną frakcją wyrzutową oraz hiperkalcemia związana $\mathrm{z}$ unieruchomieniem [16]. Bisfosfoniany są także zalecane przed zabiegami ortopedycznymi w obrębie zajętych kości celem zmniejszenia ryzyka utraty krwi [16]. Leczenie bezobjawowych pacjentów wciąż budzi kontrowersje i powinno być rozpatrywane indywidualnie $\mathrm{z}$ uwzględnieniem potencjalnych korzyści oraz ryzyka terapii [16]. W razie nietolerancji lub przeciwskazań do stosowania bisfosfonianów stosuje się kalcytoninę, ze względu na wzrost ryzyka nowotworzenia, przez okres od 3 do maksymalnie 6 miesięcy [16]. Dodatkowo, w razie dolegliwości bólowych, wskazane jest stosowanie NLPZ, w bólach o dużym nasileniu leków opioidowych. W celu zapobiegania wtórnej nadczynności przytarczyc należy monitorować stężenie wapnia oraz witaminy $\mathrm{D}_{3}$, a w razie potrzeby włączyć ich suplementację (1000 mg wapnia elementarnego i $800 \mathrm{jm}$. witaminy $\mathrm{D}_{3}$ ) [1]. Z uwagi na coraz większą wiedzę o roli cytokin prozapalnych $\mathrm{w}$ patogenezie choroby Pageta, wydaje się, że nowym kierunkiem terapeutycznym będzie, jak w przypadku innych chorób reumatycznych, leczenie biologiczne. Przykładem tego jest denosumab (monoklonalne przeciwciało anty RANKL) [17], który poprzez swoje działanie hamuje osteoklastogenezę i pobudza apoptozę dojrzałych osteoklastów [10]. Opublikowano przypadek pacjenta $\mathrm{z}$ przeciwskazaniem do stosowania bisfosfonianów, jakim jest upośledzona funkcja nerek, pokazujący skuteczność leczenia denosumabem w dawce $60 \mathrm{mg}$ podawanym podskórnie. W ocenie po 15 miesiącach terapii uzyskano zmniejszenie aktywności choroby mierzone gęstością kości oraz obniżeniem wartości wskaźników biochemicznych [10]. Być może w leczeniu choroby Pageta znajdą także zastosowanie inhibitory IL-6 [10], co na razie wymaga dalszych badań klinicznych.

\section{PODSUMOWANIE}

Choroba Pageta jest chorobą o wieloletnim przebiegu i zwykle pomyślnym rokowaniu. Leczenie, którego celem jest normalizacja stężenia biochemicznych markerów metabolizmu kostnego, pozwala zahamować progresję choroby, a u części pacjentów uzyskać remisję.

\section{ABSTRACT}

Paget's disease of bone is the second in terms of prevalence, after osteoporosis, metabolic bone disease in elderly people. Due to the diverse clinical picture and asymptomatic course at the beginning of the disease, it may be difficult to diagnose it correctly. This paper presents a case of a patient with several years passing from noticing initial bone deformity in the cranial vault to first diagnosis. How- ever, the location of disease's focus within the skull is not only a problem of its distortion. The pressure of the affected bones induced on the cranial nerves may also result in worsening of sight or deafness or other complications. Rapid implementation of bisphosphonate therapy in patients with symptoms of Paget's disease of bone may lead to remission.

Forum Reumatol. 2018, tom 4, nr 4: 238-242

Key words: Paget's disease; ethiopatogenesis; pharmacotherapy
1. Korkosz M. Choroba Pageta ed. In: Interna Szczeklika. Medycyna Praktyczna, Kraków 2015: 2021-2023.

2. Horst-Sikorska W, Grygiel-Górniak B. Choroba Pageta kości. . Medical Tribune wyd. In: Puszczewicz M. ed. Reumatologia. Wielka Interna. Wyd. II. Medical Tribune, Warszawa 2017: 493-497.

3. Langston AL, Ralston SH. Management of Paget's disease of bone. Rheumatology (Oxford). 2004; 43(8): 955-959, doi: 10.1093/rheumatology/keh243, indexed in Pubmed: 15187244.
4. Britton C, Brown S, Ward L, et al. The Changing Presentation of Paget's Disease of Bone in Australia, A High Prevalence Region. Calcif Tissue Int. 2017; 101(6): 564-569, doi: 10.1007/s00223-017-0312-1, indexed in Pubmed: 28884211.

5. Cundy $T$. Is the prevalence of Paget's disease of bone decreasing? J Bone Miner Res. 2006; 21 Suppl 2: P9-13, doi: 10.1359/jbmr.06s202, indexed in Pubmed: 17229016.

6. Chmielewski D. Choroba Pageta kości, Post Nauk Med. 2008; 6: 413-419. 
7. Whyte MP, Tau C, McAlister WH, et al. Juvenile Paget's disease with heterozygous duplication within TNFRSF11A encoding RANK. Bone. 2014; 68: 153-161, doi: 10.1016/j. bone.2014.07.019, indexed in Pubmed: 25063546.

8. Rebel A, Malkani K, Baslé M, et al. Is Paget's disease of bone a viral infection? Calcif Tissue Res. 1977; 22 Suppl: 283-286, indexed in Pubmed: 912532.

9. Basle M, Rebel A, Pouplard A, et al. [Demonstration by immunofluorescence and immunoperoxidase of an antigen of the measles type in the osteoclasts of Paget's disease of bone]. Bull Assoc Anat (Nancy). 1979; 63(182): 263-272, indexed in Pubmed: 233348.

10. Numan MS, Amiable N, Brown JP, et al. Paget's disease of bone: an osteoimmunological disorder? Drug Des Devel Ther. 2015; 9: 4695-4707, doi: 10.2147/DDDT.S88845, indexed in Pubmed: 26316708.

11. Visconti MR, Usategui-Martin R, Ralston SH. Antibody Response to Paramyxoviruses in Paget's Disease of Bone. Calcif Tissue Int. 2017; 101(2): 141-147, doi: 10.1007/s00223017-0265-4, indexed in Pubmed: 28361207.

12. Schmidt W, Tąpolska M, Pawlak-Buś K, et al. Choroba Pageta - kości patogeneza, obraz kliniczny, rozpoznanie i leczenie . Forum Reumatolog. 2017; 3(2): 81-87.
13. Verma V, Puri A, Shah S, et al. Giant Cell Tumor Developing in Paget's Disease of Bone: A Case Report with Review of Literature. J Orthop Case Rep. 2016; 6(4): 103-107, doi: 10.13107/jocr.2250-0685.594, indexed in Pubmed: 28164066.

14. Shankar S, Hosking DJ. Biochemical assessment of Paget's disease of bone. J Bone Miner Res. 2006; 21 Suppl 2: P22-P27, doi: 10.1359/jbmr.06s204, indexed in Pubmed: 17229003.

15. Cundy T, Maslowski K, Grey A, et al. Durability of Response to Zoledronate Treatment and Competing Mortality in Paget's Disease of Bone. J Bone Miner Res. 2017; 32(4): 753-756, doi: 10.1002/jbmr.3029, indexed in Pubmed: 27808435.

16. Wat WZ. Current perspectives on bisphosphonate treatment in Paget's disease of bone. Ther Clin Risk Manag. 2014; 10: 977-983, doi: 10.2147/TCRM.S58367, indexed in Pubmed: 25429226.

17. Sabharwal R, Gupta $S$, Sepolia $S$, et al. An Insight in to Paget's Disease of Bone. Niger J Surg. 2014; 20(1): 9-15, doi: 10.4103/1117-6806.127098, indexed in Pubmed: 24665195 . 